\title{
Toxicon
}

Toxicon 39 (2001) 679-685

www.elsevier.com/locate/toxicon

\section{Screening of expression libraries using ELISA: identification of immunogenic proteins from Tityus bahiensis and Tityus serrulatus venom}

\author{
E. Kalapothakis ${ }^{\mathrm{a}, *}$, S. Jardim ${ }^{\mathrm{a}}$, A.C. Magalhães ${ }^{\mathrm{a}}$, T.M. Mendes ${ }^{\mathrm{a}}$, L. De Marco ${ }^{\mathrm{a}}$, \\ L.C.C. Afonso ${ }^{\mathrm{b}}$, C. Chávez-Olórtegui ${ }^{\mathrm{c}}$ \\ ${ }^{a}$ Divisão de Biologia Celular, Departamento de Farmacologia, ICB, Universidade Federal de Minas Gerais, Av. Antônio Carlos 6627 Belo \\ Horizonte, MG 31-270901, Brazil \\ ${ }^{\mathrm{b}}$ Departamento de Ciências Biológicas, ICEB-NUPED, Universidade Federal de Ouro Preto, Ouro Preto, MG 35-400 000, Brazil \\ ${ }^{\mathrm{c}}$ Fundação Ezequiel Dias, Rua Conde Pereira Carneiro 80, Belo Horizonte, MG 30550-010, Brazil
}

Received 6 January 2000; accepted 20 June 2000

\begin{abstract}
The present report describes the use of ELISA with cDNA expression libraries in the identification of immunogenic proteins. The methodology described was applied using libraries constructed with mRNA isolated from Tityus serrulatus and Tityus bahiensis venom glands. In addition we describe for the first time the sequence of a neurotoxin from Tityus bahiensis venom gland named TbTx 5 whose amino acid sequencing showed 93\% similarity with the Tityus bahiensis TbTx IV-5 neurotoxin. The methodology described can be used for the generation of an immunogenic bank in order to contribute to genome and proteome projects. (C) 2000 Elsevier Science Ltd. All rights reserved.
\end{abstract}

Keywords: Screening; Expression library; ELISA; Genome; Proteome; Tityus bahiensis; Tityus serrulatus

\section{Introduction}

The identification of antigenic proteins from a specific tissue or even from the whole organism is very important in areas such as toxinology and parasitology. To this end, specific antibodies have been successfully used to isolate genes from expression libraries (Young and Davis, 1983;

Abbreviations: Bp, base pair(s); Da, daltons; EDTA, ethylenediamine tetra acetic acid; Ig, immunoglobulin; IPTG, isopropyl- $\beta$-Dthiogalactoside; $\mathrm{Kb}$, kilobase(s); PBS, phosphate buffered saline; PCR, polymerase chain reaction; SDS, sodium dodecyl sulfate; TAE, tris-acetate-EDTA buffer; TBS, tris-buffered saline; Ts, Tityus serrulatus scorpion; Tb, Tityus bahiensis scorpion; TstFG50, Tityus serrulatus toxic fraction purified through Sephadex G50; Xgal,

5-bromo-4-chloro-3-indolyl- $\beta$-D-galactoside

* Corresponding author. Tel.: +55-31-4992713; fax: +55-314992695.

E-mail address: ekalapo@mono.icb.ufmg.br (E. Kalapothakis).
Sambrook et al., 1989). The protocol used involves antibodies that must be as pure as possible in terms of immunological activity. However, a major problem with this technique is the cross-reactivity with proteins produced by different host cells leading to a difficult interpretation of the results obtained on nitrocellulose or nylon membranes. In addition, antibodies that do not react strongly with an antigen are normally difficult to use. In the present report we describe the use of an enzyme-linked immunosorbent assay - ELISA, (Engvall and Perlmann, 1971) to screen expression libraries. The rationale behind this approach involves the specificity of ELISA and the possibility to quantify the immunological signal on ELISA microtitration plates. In addition, we have found that this methodology can generate a large amount of information within a short period of time and can contribute to genome and proteome projects by the identification of proteins and toxins important for the development of antivenoms for clinical use. The system has been established using Tityus bahiensis and Tityus serrulatus venom gland cDNA libraries. 


\section{Materials and methods}

\subsection{General molecular biology}

Standard recombinant DNA techniques (plasmid purification, phenol extraction, ethanol precipitation, electrophoresis, etc.) were carried out as described by Sambrook et al. (1989).

\subsubsection{Construction and analysis of the venom-gland $c D N A$ library}

Venom glands from 50 Tityus bahiensis scorpions were removed 2 days after venom extraction. The glands were frozen immediately, pulverized with a mortar and pestle in liquid nitrogen and lysed in the presence of guanidinium thiocyanate according to the published procedures (Chomczynsky and Sacchi, 1987). Total RNA was passed through an oligo(dT)-cellulose column as described by Sambrook et al. (1989). Complementary DNA synthesis was performed using the ZAP-cDNA synthesis kit (Stratagene). The cDNA molecules were prepared from $5 \mu \mathrm{g}$ of Tityus bahiensis venom gland mRNA and inserted directionally into a Uni-Zap $^{\text {TM }}$ XR vector at the XhoI and EcoR I sites. The vector was subsequently packaged into viable lambda ZAP phage particles using the Gigapack II Packaging Extracts Kit (Stratagene). The insert sizes were analyzed by PCR (Saiki et al., 1988) using the primers M13R $\left(5^{\prime}\right.$ GGAAACAGCTATGACCATG $\left.3^{\prime}\right)$ and M13U (5' GTAAAACGACGGCCAGT $3^{\prime}$ ). PCR was carried out using plasmids isolated from the total library. The Tityus serrulatus venom gland cDNA library has been described by Guatimosim et al. (1999) and was also constructed as described above.

\subsubsection{Animals and venoms}

Adult female New Zealand white rabbits $(2.0-2.5 \mathrm{~kg}$ ) were used and maintained at the Fundação Ezequiel Dias (FUNED), Belo Horizonte, Brazil. All animals received water and food under controlled environmental conditions. T. serrulatus scorpions were collected near the town of Santa Bárbara, Minas Gerais, Brazil. T. bahiensis were collected in the Town of Ouro Preto, Minas Gerais, Brazil. The venom from mature animals was obtained by electric stimulation, pooled, lyophilized and stored at $-20^{\circ} \mathrm{C}$ in the dark before use.

\subsubsection{Preparation of antibodies}

The immunization protocol was carried out in rabbits as described by Chávez-Olórtegui et al. (1993) using $100 \mu \mathrm{g}$ of total venom (Tityus serrulatus or Tityus bahiensis) or $20 \mu \mathrm{g}$ of purified toxins from the venom of Tityus serrulatus: $\alpha$ type toxin tityustoxin (TsTx) (Gomez and Diniz, 1966; also called toxin IV-5 by Possani et al. (1981) or Ts IV by Martin-Eauclaire et al. (1994)), and the $\beta$-type toxin TsTx I (Toledo and Neves, 1976; also called Ts VII by Bechis et al. (1984) and toxin- $\gamma$ by Possani et al. (1985)). Booster injections of $20 \mu \mathrm{g}$ of toxin in incomplete Freund's adjuvant were made 1, 2, 3 and 4 weeks later. Immune sera were collected 10 days after the last injection and analysed by Western blotting and ELISA. Anti-TsTx and anti-TsTxI sera were further purified as described by Chávez-Olórtegui et al. (1994). The chromatographic profile obtained by reverse-phase high-performance liquid chromatography showed a single peak, suggesting that TsTx and TsTxI were homogeneous, in good agreement with the results of SDS-PAGE electrophoresis for basic proteins. The specific activity and titration of serum from rabbits immunized was carried out as described by Chávez-Olórtegui et al. (1997).

\subsubsection{Western blotting}

Eletrophoresis for basic proteins (Reisfeld et al., 1962) was performed using the BIO-RAD, Mini-Protean II system with $15 \%$ polyacrylamide gels and $30 \mu \mathrm{g}$ total protein per lane as determined by protein assay (Lowry et al., 1951). Gels were electrophoretically blotted as follows: nitrocellulose membranes $(0.45 \mu \mathrm{m}$, Schleicher and Schuell) containing the venom transferred from the polyacrylamide gels were blocked for $1 \mathrm{~h}$ in $0.3 \%$ Tween-20/PBS and then exposed to the first antibody diluted $1: 100$ in $0.05 \%$ Tween20/PBS, for $1 \mathrm{~h}$ at $37^{\circ} \mathrm{C}$ or overnight at $4^{\circ} \mathrm{C}$. After 6 washes in $0.05 \%$ Tween-20/PBS the membranes were incubated in $0.05 \%$ Tween-20/PBS containing anti-rabbit-IgG conjugated for $1 \mathrm{~h}$ at room temperature. The membranes were washed 3 times in $0.05 \%$ Tween-20/PBS and twice in PBS and then stained using $1 \mathrm{mg} \quad \mathrm{DAB} / \mathrm{ml}$ (3,3'diaminobenzidine, Sigma Chemical Co., St Louis, MO, USA) in PBS with $0.04 \% \mathrm{H}_{2} \mathrm{O}_{2}$ and $8.3 \%$ methanol.

\subsection{5. cDNA library screening using ELISA}

In vivo excision of the pBluescript phagemid from the Uni-Zap XR vector was carried out using the ExAssist helper phage according to manufacturer's specifications (Zap-cDNA synthesis manual, Stratagene). After excision, bacteria (E. coli strain SOLR) containing the pBluescript vector were plated onto agar $\mathrm{L}$ broth containing $100 \mu \mathrm{g} \mathrm{ml}^{-1}$ ampicillin, $200 \mu \mathrm{g} \mathrm{ml}^{-1} \mathrm{X}$-Gal (5-bromo-4chloro-3-indolyl- $\beta$-D-galactoside),$\quad 250 \mu \mathrm{g} \mathrm{ml}^{-1} \quad$ IPTG (isopropylthiogalactoside) and incubated at $37^{\circ} \mathrm{C}$ for $10 \mathrm{~h}$. Individual white colonies were picked with sterile $200 \mu \mathrm{l}$ tips and transferred to $2 \mathrm{ml}$ of $\mathrm{L}$ broth containing $100 \mu \mathrm{g} \mathrm{ml}^{-1}$ ampicillin and $0.5 \mathrm{mM}$ IPTG in a sterile $15 \mathrm{ml}$ tube. The collected material was allowed to grow at $37^{\circ} \mathrm{C}$ for $8-10 \mathrm{~h}$ and harvested by centrifugation ( $3000 \mathrm{~g}$ for $5 \mathrm{~min}$ ) at $4^{\circ} \mathrm{C}$. The pellet was resuspended in $0.5 \mathrm{ml}$ of carbonate buffer $\left(15 \mathrm{mM} \mathrm{Na} \mathrm{CO}_{3}, 35 \mathrm{mM}\right.$ $\mathrm{NaHCO}_{3}, \mathrm{pH} 9.6$ and $0.5 \mathrm{mM}$ PMSF) and cells were disrupted at $4^{\circ} \mathrm{C}$ by sonication (2 pulses of $15 \mathrm{~s}$ at a power setting of 3.5$)$. The sonicated material was centrifuged at $4000 \mathrm{~g}$ for $5 \mathrm{~min}$. The supernatant $(100 \mu \mathrm{l}$ per well) was then applied to the microtitration plate (Falcon 3912, Becton Dickinson) and incubated for $8-12 \mathrm{~h}$ at $4^{\circ} \mathrm{C}$. After blocking with $1 \%$ casein in PBS for at least $1 \mathrm{~h}$ at 


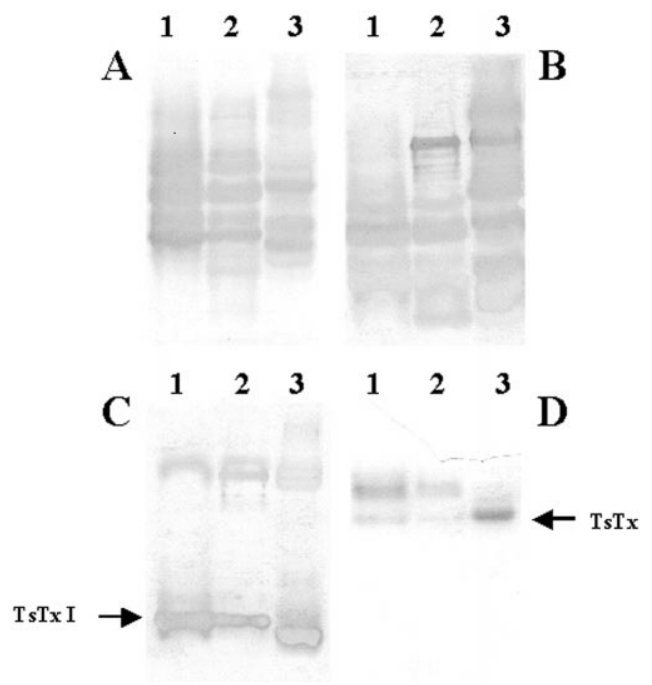

Fig. 1. Western blotting analysis of (1) Tityus serrulatus fraction TsFG50, (2) Tityus serrulatus whole venom and (3) Tityus bahiensis whole venom. The venoms were solubilized and analysed by electrophoresis on $15 \%$ polyacrylamide gels for basic proteins using $30 \mu \mathrm{g}$ total protein per lane. After transfer to nitrocellulose they were probed with a specific antibody to $T$. serrulatus whole venom (A); specific antibody to T. bahiensis whole venom (B); rabbit antiserum against $\beta$-type toxin TsTx I (C); rabbit antiserum against the $\alpha$-type toxin TsTx (D). Anti-rabbit-IgG conjugate and DAB were used to visualize the bands. TsFG50 is a Tityus serrulatus toxic fraction purified in sephadex G50 containing the major toxic components of the venom (Chávez-Olórtegui et al., 1994).

$37^{\circ} \mathrm{C}$ and washing four times with $0.15 \mathrm{M} \mathrm{NaCl}$ and $0.05 \%$ Tween 20 , the plates were incubated for $2 \mathrm{~h}$ at $37^{\circ} \mathrm{C}$ with specific antibodies diluted 1:250 in incubation buffer $(0.2 \%$ casein in PBS $+0.05 \%$ Tween 20$)$. Antibodies against the whole venom of Tityus serrulatus and Tityus bahiensis were used in the first round of screening. The plates were washed as described above and incubated for $1 \mathrm{~h}$ at $37^{\circ} \mathrm{C}$ with peroxidase-coupled anti-rabbit IgG (Sigma) diluted 1:1000 in incubation buffer. The wells were washed and the assay was completed with citrate buffer (50 mM Na $\mathrm{HPO}_{4}, 24 \mathrm{mM}$ citric acid, $\mathrm{pH} 5.0$ ), $0.2 \mathrm{mg} / \mathrm{ml}$ of OPD (o-phenylenediamine) and $0.2 \mu \mathrm{l} / \mathrm{ml}$ of $\mathrm{H}_{2} \mathrm{O}_{2}$. After incubation at $25^{\circ} \mathrm{C}$ for $20 \mathrm{~min}$ in the dark the reaction was stopped by the addition of $20 \mu \mathrm{l} /$ well of a 1:20 dilution of sulphuric acid. Absorbance values were determined at $492 \mathrm{~nm}$ with a Titertek Multiscan plate spectrophotometer. Results were confirmed by a second round of ELISA, and the positive clones were grown with and without IPTG. Total venom of Tityus serrulatus and Tityus bahiensis (100 ng/well), purified TsTx and TsTxI toxins from Tityus serrulatus (50 ng/ well) were used as positive control. As an alternative to disrupted bacteria, we used glass beads ( $3 \mathrm{~mm}$ diameter) and vortexing at high speed for $30 \mathrm{~s}$. We also found that lysozyme $\left(0.1 \mathrm{mg} / \mathrm{ml}\right.$ for $2-5 \mathrm{~min}$ at $\left.20-25^{\circ} \mathrm{C}\right)$ can improve (10-20\%) the result when used before the glass bead treatment. After cell disruption the supernatant was immediately used or stored at $-80^{\circ} \mathrm{C}$ in an ultra-low freezer before use.

\subsubsection{DNA sequencing and computer analysis}

Large scale plasmid isolations from $E$. coli were carried out according to the alkaline lysis SDS method and purified on $\mathrm{CsCl}$-ethidium bromide gradients as described by Sambrook et al. (1989). DNA sequencing reactions were performed on both strands using the chain termination method of Sanger et al. (1977). All reactions were carried out using the Automated Laser Fluorescent ALF DNA Sequencer (Pharmacia, LKB Biotechnology Inc.). Nucleic acid sequences were analysed using the MacVector ${ }^{\mathrm{TM}} 5.0$ program (Oxford Molecular Group PLC). After editing, the sequences were compared to sequences in the GenBanK databases (Altschul et al., 1997).

\section{Results and discussion}

Scorpion toxins form a family of structurally related proteins and it is expected that several of these proteins share common epitopes. In this work, the immunological cross-reactivity between Tityus serrulatus and Tityus bahiensis was demonstrated by Western blotting and also by ELISA and the results illustrated the possibility to use antibodies generated against the venom or purified toxins from one species of scorpions to isolate similar toxins in the venom of a second species (Fig. 1). In reality, toxins from both the species have shown high level of similarity at the amino acid and DNA levels (Becerril et al., 1996; Guatimosim et al., 1999).

We report here the results of a screening carried out using ELISA and expression libraries constructed with venom glands from the scorpions Tityus serrulatus and Tityus bahiensis. The Tityus bahiensis cDNA library, containing approximately $1.1 \times 10^{6}$ independent recombinants showed the presence of cDNAs corresponding to molecules of approximately 350 to $1,100 \mathrm{bp}$ (data not shown). The Tityus serrulatus cDNA library has been used by our group and contains $6.7 \times 10^{6}$ recombinants and one major class of cDNA (300-650 bp). After an initial screening of 350 colonies we found approximately $10 \%$ positive clones that showed different levels of immunoreactivity. In contrast, $90 \%$ of the clones did not show higher reactivity than the negative control (clones not induced by IPTG). The positive clones were used for further immunological characterization using purified antibodies against the TsTx and TsTxI toxins. Since the best results were obtained using the specific anti-TsTx and anti-TsTxI antibodies, we also used a pool of antibodies in the first screening, followed by the use of individual antibodies on a second plate containing positive clones and a few negative clones. The sera from immunized rabbit displayed consistent immunoreactivity with the antigens 
Table 1

ELISA results. ELISA was carried out as described in Section 2. The absorbance of pre-immune serum (control) was subtracted. Clones for which no sequencing data is available or no significant similarity has been found using GenBanK databases and Fasta program are labelled nd or ns, respectively

\begin{tabular}{|c|c|c|c|c|}
\hline \multirow[t]{2}{*}{ Tityus bahiesis cDNA library } & \multicolumn{3}{|l|}{ ELISA results } & \multirow[t]{2}{*}{ Toxin name } \\
\hline & Anti-Tb venom & Anti-TsTx & Anti-TsTx I & \\
\hline Negative control & 0.059 & 0.067 & 0.084 & - \\
\hline T. bahiensis venom & 2.275 & 0.950 & 2.497 & - \\
\hline Clone 7.1 & 0.128 & 0.647 & 0.387 & $\operatorname{TbTx} 5^{\mathrm{a}}$ \\
\hline Clone 7.10 & 0.100 & 0.721 & 0.508 & $\operatorname{TbTx} 5^{a}$ \\
\hline 7.19 & 0.103 & 0.570 & 0.395 & nd \\
\hline 7.58 & 0.096 & 0.856 & 0.481 & nd \\
\hline 7.75 & 0.143 & 0.541 & 0.348 & nd \\
\hline 7.82 & 0.172 & 0.624 & 0.401 & nd \\
\hline 24.2 & 0.369 & 0.411 & 0.304 & ns \\
\hline 24.33 & 0.268 & 0.309 & 0.328 & ns \\
\hline \multirow[t]{2}{*}{ Tityus sennulatus cDNA library } & \multicolumn{3}{|l|}{ Elisa results } & Toxin name \\
\hline & Anti-Ts venom & Anti-TsTx & Anti-TsTx I & \\
\hline Negative control & 0.052 & 0.050 & 0.063 & - \\
\hline T. serrulatus venom & 1.292 & 0.482 & 1.560 & - \\
\hline Clone 13.33 & 0.783 & 0.572 & 0.757 & TsNTxP $\mathrm{P}^{\mathrm{b}}$ \\
\hline Clone13.49 & 0.319 & 0.319 & 0.303 & TsTx I $I^{c}$ \\
\hline Clone 13.52 & 0.156 & 0.223 & 0.221 & ns \\
\hline Clone 28 & 0.163 & 0.334 & 0.283 & ns \\
\hline Clone 64 & 0.121 & 0.353 & 0.348 & $\mathrm{c}-\mathrm{TsTxK} \beta^{\mathrm{a}}$ \\
\hline Clone 68 & 0.105 & 0.350 & 0.382 & nd \\
\hline
\end{tabular}

\footnotetext{
${ }^{\text {a }}$ The present work.

b TsNTxP (Guatimosim et al., 1999).

c TsTx I (Toledo and Neves, 1976; Bechis et al., 1984; Possani et al., 1985).
}

coated on the microtitration plate, while sera from control mice did not react (data not shown).

We did not expect to detect all immunogenic proteins expressed in the venom gland since some proteins may be post-translationally modified and the $E$. coli system used in the production of the recombinant protein may not be able to modify correctly the protein. In addition, the cDNA must be in frame with the fusion protein ( $\beta$-galactosidase) and finally, the expression level is different from clone to clone and some clones could express very low levels of recombinant protein. However, several clones were identified as potential immunogenic proteins and the knowledge of these clones may be important to improve anti-serum production and quality (Table 1). This procedure does not allow to screen as many clones as membrane-lifting within a short period of time and good libraries and purified antibodies are recommended. However, this approach gives more quantitative results than the standard visual inspection of antibody signal and approximately 300 clones can be analysed by one person per week. In addition, it is specifically useful for cDNA libraries constructed with RNA isolated from tissues containing a limited number of specific clones such as venom glands. We found that the best time to induce the cells varies from clone to clone, but $8-10 \mathrm{~h}$ yielded recombinant protein detectable by ELISA for most clones. A second round of ELISA was carried out to confirm the positive signal and approximately $90 \%$ of the positive clones showed the same result (positive or negative).

Isolated clones were characterized by DNA sequencing, and several were shown to code for previously described proteins, supporting the validity of the process described (see Table 1). To illustrate the methodology, we also showed the complete sequencing of one clone isolated from the Tityus bahiensis cDNA library. In reality, two independent clones encoding for the same toxin were isolated (clone 7.1 and 7.10). The toxin described in the present study has been designated TbTx5 (Tityus bahiensis Toxin 5) since Becerril et al. (1996) has already reported the sequence of four different toxins isolated from the venom of Tityus bahiensis scorpion. The clones encode for a toxin very similar to TbTx IV-5 (93\% identity at the amino acid level). Fig. 2 shows the nucleotide sequence of the cDNA encoding the precursor of TbTx5 and also the comparison of amino acid sequence among TbTx5, TbTxIV-5 and TsTx. Sequence analysis showed that the cDNA contained a 

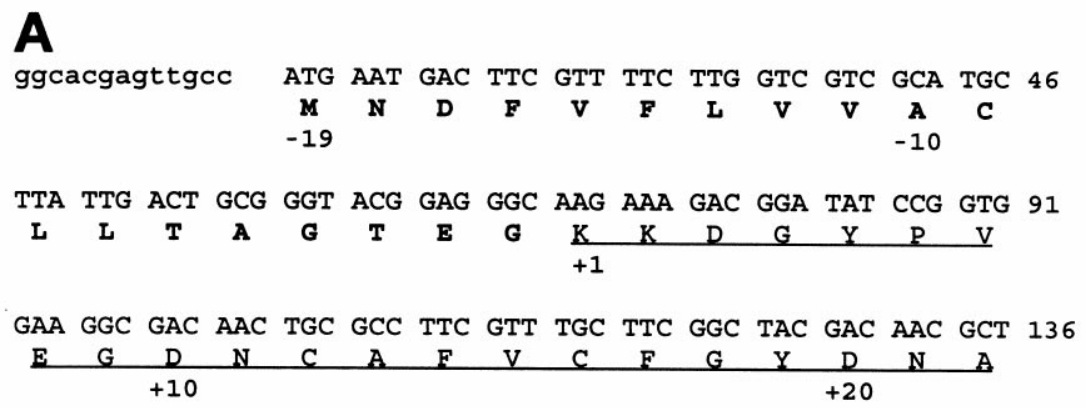

\section{B}

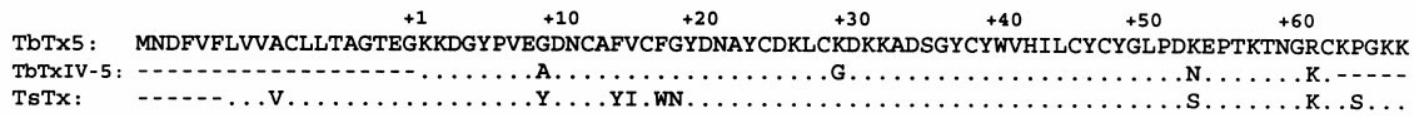

Fig. 2. (A) Nucleotide sequence of cDNA encoding TbTx5. The coding region is shown in uppercase with the $5^{\prime}$ and $3^{\prime}$ untranslated regions in lowercase. The signal peptide is indicated in bold. The segment that corresponds to the amino acid sequence of TbTx 5 is underlined. (B) Comparison of amino acid sequence of TbTx 5 with TbTx IV-5 and TsTx. TbTx IV-5 is a neurotoxin isolated from Tityus bahiensis and described by Becerril et al. (1996). TsTx (Tityustoxin) a neurotoxin from Tityus serrulatus has been described by different authors (Gomez and Diniz 1966; also called toxin IV-5 by Possani et al. (1981) or Ts IV by Martin-Eauclaire et al. (1994)). Numbering corresponding to the signal peptide is negatively numbered. When there is no similarity the corresponding change is indicated.

short $5^{\prime}$-untranslated region and an open reading frame encoding a peptide of 86 amino acids. The sequence of nucleotides 14 to 70 encodes for a signal peptide of 19 amino acids containing an initiating Met and a series of highly hydrophobic amino acids residues (Fig. 2). TbTx5 and TbTx IV-5 differ by only four residues at positions 9 (G for $\mathrm{A}), 29(\mathrm{~K}$ for $\mathrm{G}) 53(\mathrm{~K}$ for $\mathrm{N})$ and position $61(\mathrm{R}$ for $\mathrm{K}$ ) and also showed 5 extra residues at the C-terminal peptide. TbTx 5 also showed an important similarity with TsTx (also called toxin IV of Tityus serrulatus by Martin-Eauclaire et al. (1994)) showing 87\% identity at the amino acid level.

Using the Tityus serrulatus cDNA library, clones containing the nucleotide sequence encoding for TsNTxP and TsTxI were found. TsNTxp is a protein described by our group (Guatimosim et al., 1999) that proved to be highly immunogenic, and TsTx I is a neurotoxin active on sodium channel which has been described by several groups (Toledo and Neves, 1976; also called Ts VII by Bechis et al. (1984) and toxin- $\gamma$ by Possani et al. (1985)). Of interest is clone 64 called here $\operatorname{cTsTx}-\mathrm{K} \beta$ (cDNA of TsTx-K $\beta$ ), whose deduced amino acid sequence (Fig. 3) showed 64\% identity with the long chain potassium ion channel blocker BmTxK $\beta 2$ isolated from the scorpion Buthus martensii (Zhu et al., 1999), approximately $91 \%$ with the toxin TsTx-K $\beta$ described by Rogowski et al. (1994) and its sequence is almost identical to the partial sequence of clones $\mathrm{Ts}-5^{\prime} \mathrm{Cl} .14$ and $\mathrm{Ts}-3^{\prime} \mathrm{Cl} .3$ published by Legros et al. (1998). However, a deletion of a guanine base at 


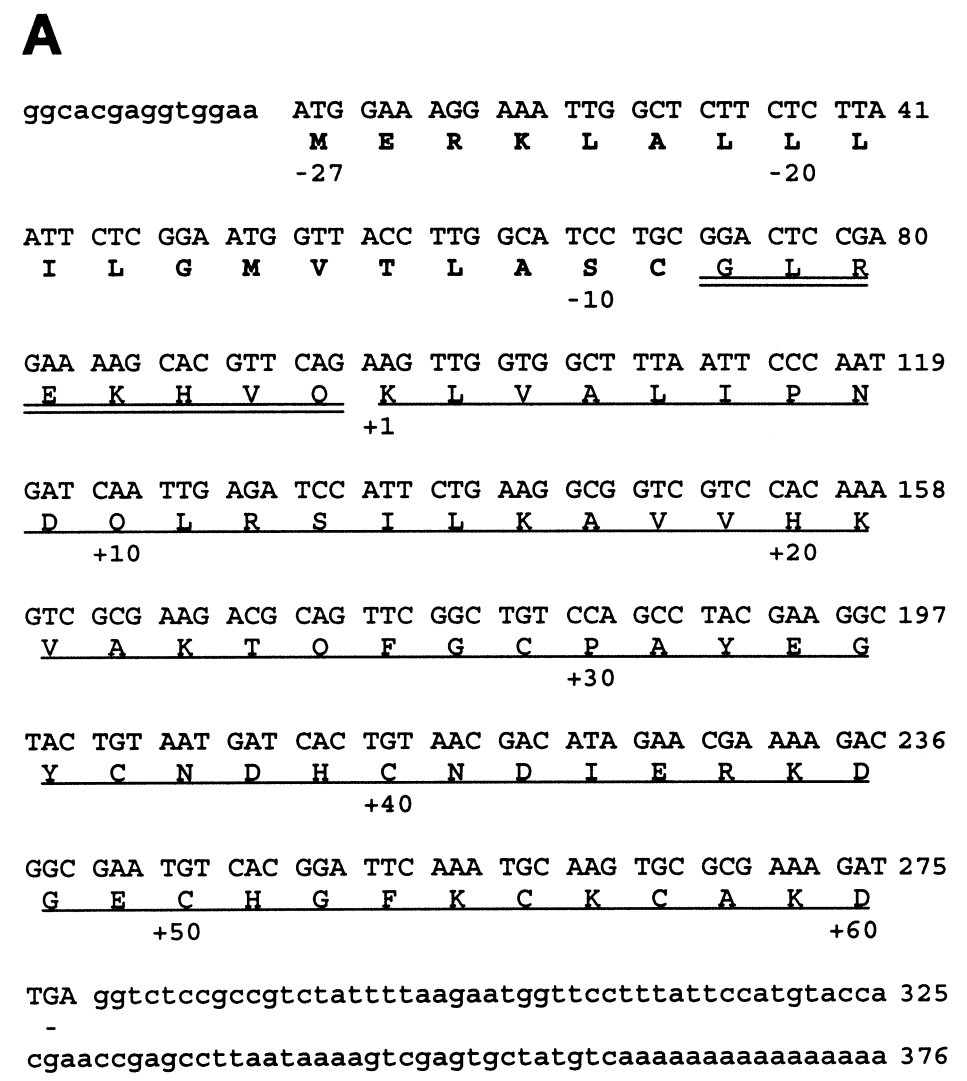

B

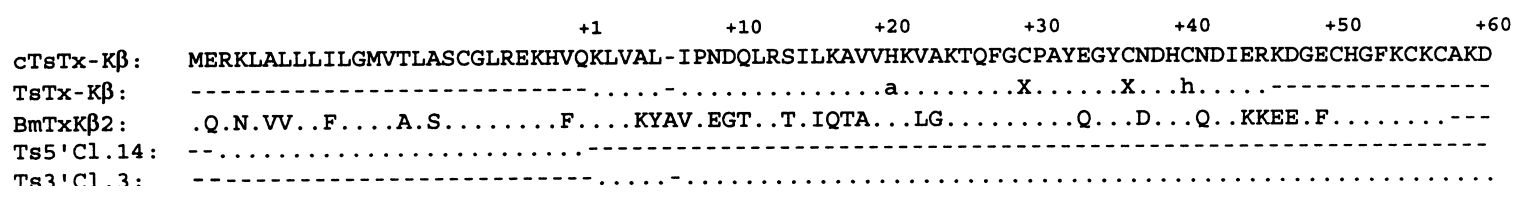

Fig. 3. (A) Nucleotide sequence of cDNA encoding cTsTxK $\beta$. The hydrophobic region (signal peptide) is indicated (bold), the putative propeptide is underlined twice and the segment that corresponds to the amino acid sequence of cTsTxK $\beta$ is underlined. (B) Comparison of amino acid sequence of $\operatorname{cTsTxK} \beta$ with BmTxK $\beta 2$ (a putative potassium ion channel blocker from Buthus martensii, Zhu et al., 1999); TsTx-K $\beta$ (potassium ion channel blocker from Titus serrulatus, Rogowski et al., 1994) and clones Ts5'Cl.14 and Ts $3^{\prime} \mathrm{Cl} .3$ (Legros et al., 1998). Numbering corresponding to the signal peptide is negatively numbered. When there is no similarity the corresponding change is indicated.

position 102 of this clone was observed and the most likely conclusion is that this deletion is probably a cloning artefact. The toxin encoded by clone cTsTx-K $\beta$ also showed $48 \%$ identity with a defensin isolated from the scorpion Leiurus quinquestriatus hebraeus (Cociancich et al., 1988). Finally, no significant similarity was found for some other isolated clones after DNA sequence analysis using GenBanK databases and the Fasta program of Pearson and Lipman (1988).

In conclusion, we described the use of ELISA in the 
screening of expression libraries. The methodology shows good potential for the identification of antigenic proteins and could be very useful for groups interested in information from a specific tissue or organism.

\section{Acknowledgements}

The work was supported by PADCT, FAPEMIG, CNPq and PRONEX.

\section{References}

Altschul, S.F., Madden, T.T.L., Schäffer, A.A., Zhang, J., Zhang, Z., Miller, W., Lipman, D.J., 1997. Gapped BLAST and PSIBLAST: a new generation of protein database search programs. Nucleic Acids Res. 25, 3389-3402.

Becerril, B., Corona, M., Coronas, F.I., Zamudio, F., CalderonAranda, E.S., Fletcher Jr., P., Martin, B.M., Possani, L.D., 1996. Toxic peptides and genes encoding toxin gamma of the Brazilian scorpions Tityus bahiensis and Tityus stigmurus. Biochem. J. 313, 753-760.

Bechis, G., Sampieri, F., Yuan, P.M., Brando, T., Martin, M.F., Diniz, C.R., Rochat, H., 1984. Amino acid sequence of Toxin VII, a beta-toxin from the venom of the scorpion Tityus serrulatus. Biochem. Biophys. Res. Commun. 122, 1146-1153.

Chávez-Olórtegui, C., Lopes, C.S., Cordeiro, F.D., Granier, C., Diniz, C.R., 1993. An enzyme linked immusorbent assay (ELISA) that discriminates between Bothrops atrox and Lachesis muta muta venoms. Toxicon 32, 1649-1656.

Chavez-Olortegui, C., Fonseca, S.C., Campolina, D., Amaral, C.F., Diniz, C.R., 1994. ELISA for the detection of toxic antigens in experimental and clinical envenoming by Tityus serrulatus scorpion venom. Toxicon 32, 1649-1656.

Chavez-Olortegui, C., Kalapothakis, E., Ferreira, A.M., Ferreira, A.P., Diniz, C.R., 1997. Neutralizing capacity of antibodies elicited by a non-toxic protein purified from the venom of the scorpion Tityus serrulatus. Toxicon 35, 213-221.

Chomczynski, P., Sacchi, N., 1987. Single-step method of RNA isolation by acid guanidinium thiocyanate-phenol-cholorofom extraction. Anal. Biochem. 162, 156-159.

Cociancich, S., Goyffon, M., Bontems, F., Bulet, P., Bouet, F., Menez, A., Hoffmann, J., 1993. Purification and characterization of a scorpion defensin, a $4 \mathrm{kDa}$ antibacterial peptide presenting structural similarities with insect defensins and scorpion toxins. Biochem. Biophys. Res. Commun. 194, 17-22.

Engvall, E., Perlmann, P., 1971. Enzyme-linked immunosorbent assay (ELISA): quantitative assay of immunoglobin G. Immunochemistry 8, 871-874.

Gomez, M.V., Diniz, C.R., 1966. Separation of toxic componennts from the Brazilian scorpion Tityus serrulatus venom. Mem. Inst. Butantan, Simp. Internac. 33, 899-902.
Guatimosim, S.C.F., Prado, V.F., Diniz, C.R., Chávez-Olórtegui, C., Kalapothakis, E., 1999. Molecular cloning and genomic analysis of TsNTxP: an immunogenic protein from Tityus serrulatus scorpion venom. Toxicon 37, 507-517.

Legros, C., Ceard, B., Bougis, P.E., Martin-Eauclaire, M.F., 1998. Evidence for a new class of scorpion toxins active against $\mathrm{K}+$ channels. FEBS Lett. 431, 375-380.

Lowry, O.H., Rosebrowgh, N.J., Farr, A.L., Randall, R.J., 1951. Protein measurement with the Folin phenol reagent. J. Biol. Chem. 193, 265-275.

Martin-Eauclaire, M.F., Céard, B., Ribeiro, A.M., Diniz, C.R., Rochat, H., Bougis, P.E., 1994. Biochemical, pharmacological and genomic characterisation of TsIV, an alpha-toxin from the venom of the south American scorpion Tityus serrulatus. FEBS Lett. 342, 181-184.

Pearson, W.R., Lipman, D.J., 1988. Improved tools for biological sequence comparison. Proc. Natl. Acad. Sci. USA 85, 2444-2448.

Possani, L.D., Martin, B.M., Mochca-Morales, J., Svendsen, I., 1981. Purification and chemical characterization of the major toxins from the venom of the Brazilian scorpion Tityus serrulatus Lutz and Mello. Carlsberg Res. Commun. 46, 195-205.

Possani, L.D., Martin, B.M., Svendsen, I., Rode, G.S., Erickson, B.W., 1985. Scorpion toxins from Centruroides noxius and Tityus serrulatus. Biochem. J. 229, 739-750.

Reisfeld, R.A., Lewis, U.J., Williams, D.E., 1962. Disk electrophoresis of basic proteins and peptides on polyacrylamide gels. Nature 195, 281-283.

Rogowski, R.S., Krueger, B.K., Collins, J.H., Blaustein, M.P., 1994. Tityustoxin K alpha blocks voltage-gated noninactivating $\mathrm{K}+$ channels and unblocks inactivating $\mathrm{K}+$ channels blocked by alpha-dendrotoxin in synaptosomes. Proc. Natl. Acad. Sci. USA 15, 1475-1479.

Saiki, R.K., Gelfand, D.H., Stoffel, S., Scharf, S.J., Higuchi, R., Horn, G.T., Mullis, K.B., Erlich, H.A., 1988. Primer-directed enzymatic amplification of DNA with a thermostable DNA polymerase. Science 252, 1643-1651.

Sambrook, J., Fritsh, E.F., Maniats, T., 1989. Molecular Cloning: A Laboratory Manual, vols. 1-3, Cold Spring Harbor, New York.

Sanger, F., Nicklen, S., Coulson, A.R., 1977. DNA sequencing with chain termination inhibitors. Proc. Natl. Acad. Sci. USA 74, 5463-5467.

Toledo, D., Neves, A.G.A., 1976. Purification and partial characterization of a second toxin from the scorpion Tityus serrulatus. Comp. Biochem. Physiol. 55, 249-253.

Young, R.A., Davis, R.W., 1983. Efficient isolation of genes by using antibody probes. Proc. Natl. Acad. Sci. USA 80, 11941198.

Zhu, S., Li, W., Zeng, X., Jiang, D., Mao, X., Liu, H., 1999. Molecular cloning and sequencing of two 'short chain' and two 'long chain' $\mathrm{K}(+)$ channel-blocking peptides from the Chinese scorpion Buthus martensii Karsch. FEBS Lett. 457, 509-514. 